\title{
Relationship between Pectic Substances and Strand Separation of Cooked Spaghetti Squash-Part 1. Changes in Pectic Substances during Cooking
}

\author{
Kayoko Ishii ${ }^{1}$, Ai Teramoto ${ }^{2}$, Hiroko Kuwada ${ }^{1}$, Chihiro Nakazaki ${ }^{1}$, Yuri Jibu ${ }^{3}$, Mayumi Tabuchi ${ }^{3}$ and Michiko \\ Fuchigami $^{1}$ \\ 1. Department of Nutrition and Life Science, Fukuyama University, Fukuyama 729-0292, Japan \\ 2. Department of Health and Nutrition, Kanto Gakuin University, Yokohama 236-8501, Japan \\ 3. Department of Nutritional Science, Okayama Prefectural University, Soja 719-1197, Japan
}

\begin{abstract}
The purpose of this paper is to investigate the relationship between pectic substances and the separation into strands during cooking of spaghetti squash. Spaghetti squash flesh separated into strands when boiled. Pectic substances of raw and cooked flesh were fractionated into three reagents. The galacturonic acid compositions of hydrochloric acid ( $\mathrm{HCl}$ )-soluble pectin (PA), sodium acetate buffer-soluble pectin (PB) and sodium hexametaphosphate-soluble pectin (PC) of raw flesh were $69.0 \%, 28.9 \%$ and $2.1 \%$, respectively. Also, the degree of esterification (DE) of PA, PB and PC was $67.4 \%, 61.5 \%$ and $55.6 \%$, respectively. The DE of pectin was from the greatest to the least: $\mathrm{PA}>\mathrm{PB}>\mathrm{PC}$, respectively, and the diethylaminoethyl (DEAE)-cellulose column chromatograms of $\mathrm{PA}$ and $\mathrm{PB}$ showed that they were comparatively in high methoxyl pectin. Therefore, about $50 \%$ of pectic substances in flesh were released into a cooking solution during 15-30 min of cooking. Highmethoxylpectin was degraded by $\beta$-elimination during boiling. Consequently, the flesh was separated into strands. This suggests that highmethoxylpectin glues strands together in the flesh of spaghetti squash.
\end{abstract}

Key words: Spaghetti squash, pectin, texture, structure, strand separation, cooking.

\section{Introduction}

Spaghetti squash (Cucurbita pepo L.) is one of the hard-shelled squashes in the cucurbit family and typically grown as a winter squash. It is an American native vegetable. It is rugby ball sized and oval-shaped and the rind is hard and ivory colored at maturity. Its center contains many large squash seeds. It has a mild taste and crisp texture and may be boiled, steamed, baked or microwaved. When cooked, the flesh can be pulled apart to form strands that resemble spaghetti, hence its name.

Pectin is the main component of the middle lamella. It contributes to adhesion between parenchyma cells of vegetables and mechanical strength of tissues.

Corresponding author: Hiroko Kuwada, Ph.D., research assistant, research field: cookery science. E-mail: kuwada@fubac.fukuyama-u.ac.jp.
Maceration of vegetable tissues seems to be brought about mainly by the degradation of pectin [1]. The softening of vegetables during cooking is affected by the properties of pectic substances, especially the degree of esterification (DE) [2-5].

A method of fractional extraction of pectic substances under a mild condition has been reported [2]. Extraction was done successively with three reagents: $\mathrm{HCl}$, sodium acetate buffer and sodium hexametaphosphate solutions. While dipping tissues in $0.01 \mathrm{~N} \mathrm{HCl}(\mathrm{pH} 2.0)$ solution at $35^{\circ} \mathrm{C}$, high methoxyl pectin was extracted due to removal of polyvalent cations, such as $\mathrm{Ca}^{2+}$, because low methoxyl pectin is usually precipitated at $\mathrm{pH}$ 2.0. After repeating the extraction with $0.01 \mathrm{~N} \mathrm{HCl}$ solution, the residue was extracted with of $0.1 \mathrm{M}$ acetate buffer solution ( $\mathrm{pH} 4.0$ ) at $35{ }^{\circ} \mathrm{C}$. The last extraction was done with $2 \%$ sodium hexametaphosphate solution $(\mathrm{pH} 4.0)$ at $90{ }^{\circ} \mathrm{C}$ for $3.5 \mathrm{~h}$. 
The vegetables which were easily softened by thermal treatment, contained more $\mathrm{HCl}$-soluble pectin (high methoxyl pectin, pectin A, PA) than the sodium acetate buffer soluble pectin (low methoxyl pectin, pectin $\mathrm{B}, \mathrm{PB})[2-5]$. The high methoxyl pectin easily broke down in a hot neutral solution and alkaline solutions by $\beta$-elimination [6, 7]; therefore, vegetables with a greater amount of PA had decreased intercellular adhesion strength. Conversely, the vegetables which had a larger amount of PB were difficult to soften during cooking [2-5].

Therefore, the cause of the separation into strands during boiling of spaghetti squash seems to be pectic substances which play a substantial role in the maintenance of intercellular cohesion, especially high methoxyl pectin which breaks down by cooking. Thus, the purpose of this paper is to investigate the relationship between spaghetti squash pectic substances and the separation into strands during cooking.

\section{Materials and Methods}

\subsection{Sample Preparation and Cooking Procedure}

Spaghetti squash $(1,392 \mathrm{~g} \pm 432 \mathrm{~g}$, harvested in Okayama, Japan, obtained in July) was cut into $2 \mathrm{~cm}$ long crosswise pieces, peeled and the seeds were discarded. Flesh samples $(100 \mathrm{~g})$ were dropped into boiling distilled water $(1,000 \mathrm{~mL})$ in a $1,000 \mathrm{~mL}$ beaker and cooked for $15 \mathrm{~min}$ or $30 \mathrm{~min}$, stirring at short intervals. Then they were strained and weighed.

\subsection{Structure Measurements}

Histological structures of raw and cooked (for 15 min or $30 \mathrm{~min}$ ) samples were observed using a light microscope (LM). Samples were cut in blocks of 1 $\mathrm{mm}^{3}$. Tissue blocks were fixed in a $3 \%$ glutaraldehyde solution buffered at $\mathrm{pH} 7.4$ with a $0.01 \mathrm{M}$ phosphate buffer for $17 \mathrm{~h}$ at $4{ }^{\circ} \mathrm{C}$, and then post-fixed in $1 \% \mathrm{OsO}_{4}$ solution buffered with the same buffer for $2 \mathrm{~h}$. After dehydration through graded concentration of ethanol, specimens were embedded in Epok 812. All specimens were cut at $1 \mu \mathrm{m}$ with an ultramicrotome and stained with toluidine blue for observation with a LM [8].

\subsection{Extraction of Pectin}

Pectic substances of raw and cooked (for $15 \mathrm{~min}$ and $30 \mathrm{~min}$ ) samples (10 g) were successively extracted as follows: $0.01 \mathrm{~N} \mathrm{HCl}$ (at pH 2.0 and $35{ }^{\circ} \mathrm{C}$ for $24 \mathrm{~h} \times 4$ times), $0.1 \mathrm{M}$ sodium acetate buffer (at $\mathrm{pH} 4.0$ and $35{ }^{\circ} \mathrm{C}$ for $24 \mathrm{~h} \times 4$ times) and $2 \%$ sodium hexametaphosphate solution (at pH 4.0 and $90{ }^{\circ} \mathrm{C}$ for $3.5 \mathrm{~h} \times 3$ times) [2-5]. Each extraction was repeated until no sugar was detected. Each extract was concentrated at $\mathrm{pH} 4.0$ and dialyzed against distilled water at $5{ }^{\circ} \mathrm{C}$ for two days. These extracts were designated as $\mathrm{PA}$ [hydrochloric acid $(\mathrm{HCl})$-soluble pectin], PB (sodium acetate buffer-soluble pectin) and PC (sodium hexametaphosphate-soluble pectin), respectively. The amount of galacturonic acid was determined by the carbazole method [9].

\subsection{Determinations of Esterification of Pectin and Dietary Fiber}

The DE of PA, PB and PC were determined using a gas-chromatographic procedure [10]. The dietary fibers (cellulose, hemi-cellulose and lignin) were determined by the method of Van Soest \& Wine [11].

\subsection{Diethylaminoethyl (DEAE)-Cellulose Column Chromatography}

The DEAE-cellulose column chromatography of PA, $\mathrm{PB}$ and $\mathrm{PC}$, extracted from raw and 15 min cooked flesh, was performed by the same method reported previously $[4,5]$. The pectic substances (about $10 \mathrm{mg}$ of galacturonic acid) were added to a DEAE-cellulose column ( $2 \mathrm{~cm}$ in diameter, $5 \mathrm{~cm}$ long) equilibrated with a $0.02 \mathrm{M}$ acetate buffer solution ( $\mathrm{pH}$ 6.0). The column was first washed with an equilibrating buffer solution (fraction I) and then eluted successively with 0.1-1 M sodium acetate buffer solution of $\mathrm{pH} 6.0$ (linear gradient, fraction II) and $0.1 \mathrm{~N} \mathrm{NaOH}$ (fraction III). The fractions were monitored by the phenol sulphuric acid method [12] and the carbazole method [9]. The 
amount of neutral sugar was calculated by the method of Hatanaka and Ozawa [13]. Monosaccharides were analyzed by the gas chromatographic procedure [14].

\subsection{Gel-Filtration}

The three fractions separated by DEAE-cellulose column chromatography were dialyzed against distilled water after concentrating at $\mathrm{pH} 4.0$, and were then added to a sepharose CL-6B column $(2 \mathrm{~cm}$ in diameter, $80 \mathrm{~cm}$ long) equilibrated with a $0.02 \mathrm{M}$ acetate buffer solution ( $\mathrm{pH}$ 4.0). The column was eluted with the same solution, the fractions being monitored by the same method as that just described. Blue dextran (average molecular weight (MW, $2 \times$ $\left.10^{6}\right)$ ), Dextran T500 (MW, 539,000), Dextran T40 (MW, 39,400) and Dextran T10 (MW, 9,500) were used as standard [15].

\section{Results and Discussion}

\subsection{Changes in Visual Appearances of Spaghetti} Squash during Cooking

Changes in visual appearances of spaghetti squash during cooking are shown in Fig. 1. Appearance of a whole fruit is a cylindrical fruit with hard rind (Fig. 1a). When it was cut into $2 \mathrm{~cm}$ long pieces in crosswise (Fig. 1b), an off-white flesh such as a long thread adhered in the shape of an eddy. There were many large seeds in the center of squash.

The squash was peeled and the seeds were discarded, then flesh samples were cooked for $15 \mathrm{~min}$ or $30 \mathrm{~min}$ in a beaker, stirring at short intervals. The $\mathrm{pH}$ values of cooking solution were $5.80 \pm 0.16$ and $5.83 \pm 0.13$ after cooking for $15 \mathrm{~min}$ and $30 \mathrm{~min}$, respectively. After cooking for $15 \mathrm{~min}$ (Fig. 1c) or $30 \mathrm{~min}$ (Fig. 1d), flesh came out in threads and separated into strands like spaghetti. When boiled for $30 \mathrm{~min}$, broth (cooking solution) became muddy. After cooking, they were strained. The strands cooked for $15 \mathrm{~min}$ (Fig. 1e) or for $30 \mathrm{~min}$ (Fig. 1f) were crunchy and watery. When spaghetti squash was halved in lengthwise, the full spaghetti-like length of strands was provided.

\subsection{Changes in Histological Structure of Spaghetti Squash during Cooking}

Changes in light micrographs of spaghetti squash during cooking are shown in Fig. 2. The micrographs of raw flesh are shown in Figs. 2a-2c. When the tissue was cut in crosswise, a vascular bundle (the mass of small cells) was observed in the center of the strand (Figs. 2a and 2c). The shape of cells which constituted the strand differed from that of cells which surrounded the strand. The former cells were round and the latter cells were elongated (Fig. 2a). When cooked, the shape of the former cells was maintained, but the latter cells, which contributed to adhesion between strands, broke down. Thus, flesh separated into strands. When
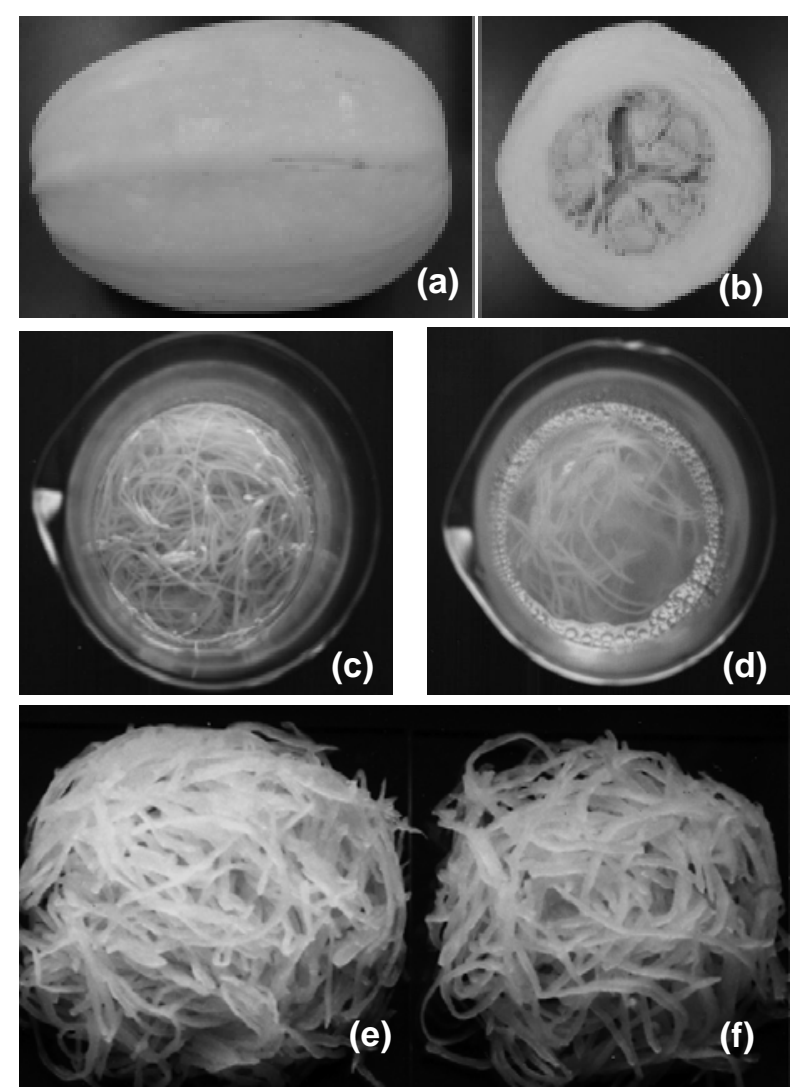

Fig. 1 Changes in visual appearances of spaghetti squash during cooking.

(a) Appearance of a whole fruit; (b) the squash cut in crosswise; (c) squash cooked for 15 min in a beaker; (d) squash cooked for30 min in a beaker; (e) the strands cooked for $15 \mathrm{~min}$; (f) the strands cooked for $30 \mathrm{~min}$. Flesh was stirred during cooking. The $\mathrm{pH}$ values of cooking solution were $5.80 \pm 0.16$ and $5.83 \pm$ 0.13 after cooking for $15 \mathrm{~min}$ and $30 \mathrm{~min}$, respectively. 

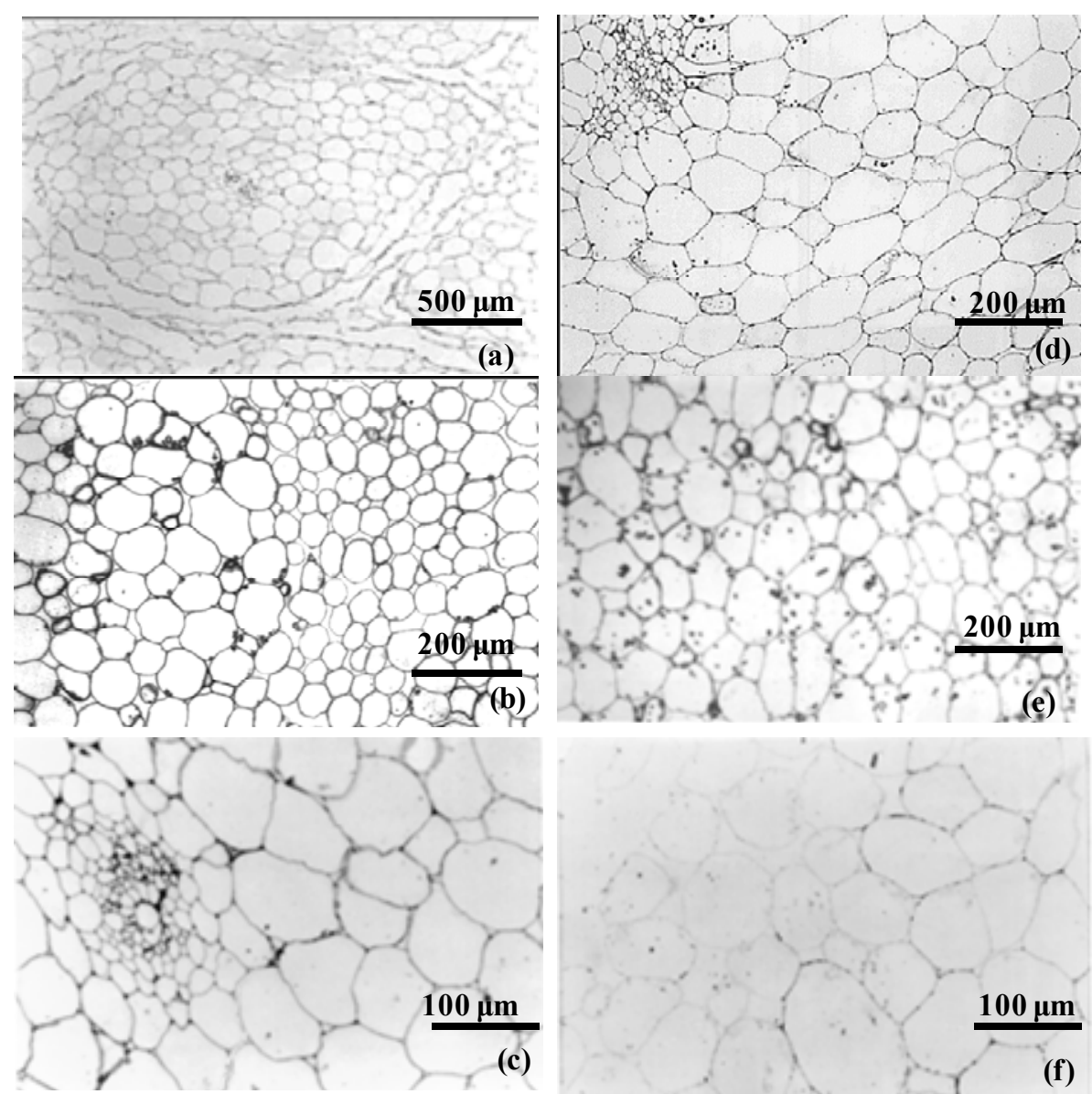

Fig. 2 Changes in light micrographs of spaghetti squash during cooking. (a), (b) and( c) raw; (d) cooked for $15 \mathrm{~min}$; (e) and (f) cooked for $30 \mathrm{~min}$.

cooked for 15 min (Fig. 2d) or 30 min (Figs. 2e and 2f), the parenchyma maintained the same structure as the raw parenchyma (Fig. 2a), although they were dyed somewhat thinly. This is regarded as a cause of crisp texture.

\subsection{Changes in Pectic Substances of Spaghetti Squash during Cooking}

The composition of pectic substances of raw and cooked spaghetti squash fractionated with three reagents is shown in Fig. 3 and Table 1. The amount (percentage) of PA, PB and PC in the raw sample was $237.4(69.0 \%), 99.6(28.9 \%)$ and $7.3 \mathrm{mg}(2.1 \%)$ per $100 \mathrm{~g}$, respectively. The percentage of PA was the greatest. After cooking for $15 \mathrm{~min}$, about $50 \%$ of pectic substances were released into cooking solution. The decrease of PA in flesh was extremely (from $237.4 \mathrm{mg}$ to $73.8 \mathrm{mg}$ per $100 \mathrm{~g}$ ). However, even if heating was continued until $30 \mathrm{~min}$, release of pectin did not increase. This suggests that pectin remaining in the strands is regarded as a cause of crisp texture.

The amount of galacturonic acid and the DE of pectic substances extracted from spaghetti squash are shown in Table 1. The DE of PA, PB and PC was $67.4 \%, 61.5 \%$ and $55.6 \%$, respectively. The percentage of PA, which was high methoxyl pectin, was the greatest. Therefore, when squash was cooked for 15 min, PA decreased greatly, because high methoxyl pectin broke down by $\beta$-elimination when it was boiled in a hot neutral solution [6]. Therefore, about $50 \%$ of pectic substances were released into cooking solution during 15-30 min cooking.

The percentage of $\mathrm{PA}, \mathrm{PB}$ and $\mathrm{PC}$ of various vegetables were compared (Table 2). The percentage of 

Changes in Pectic Substances during Cooking

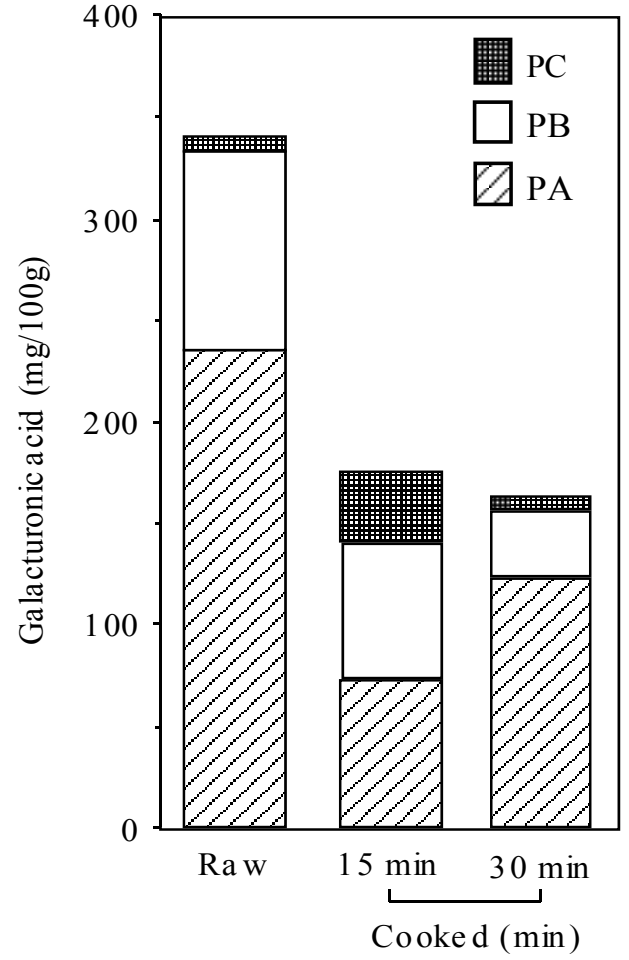

Fig. 3 Changes in pectic substances of spaghetti squash during cooking.

PA: $0.01 \mathrm{~N} \mathrm{HCl}$ soluble pectin; PB: $0.1 \mathrm{M}$ acetate buffer soluble pectin; PC: $2 \%$ sodium hexametaphosphate soluble pectin.

PA of spaghetti squash was higher than lotus, burdock and bamboo shoot. Also, the DE of pectin in spaghetti squash was higher than $\mathrm{DE}$ of the other vegetables such as lotus [2, 3], burdock [15] and bamboo shoot [5]. Thus, the squash was more easily softened than lotus, burdock and bamboo shoot after cooking.

The amount of dietary fiber is shown in Table 2 . The amounts of cellulose, hemicellulose, lignin and pectin of spaghetti squash were similar to those of Japanese radish root. It is suggested that cellulose, hemicellulose and pectin remaining in strands after cooking maintained crisp tender strands.

\subsection{Changes in DEAE-Cellulose Column}

Chromatogram and Gel-Filtration Profiles of Pectic Substances during Cooking

To investigate the properties of pectic polysaccharides in detail, $\mathrm{PA}, \mathrm{PB}$ and $\mathrm{PC}$ were fractionated into neutral and acidic polysaccharide fractions by DEAE-cellulose column chromatography. The neutral polysaccharides (100\% neutral sugar), weakly acidic polysaccharides and pectic acid are usually eluted in fractions I, II and III, respectively. High methoxyl pectin was eluted earlier and low methoxyl pectin was eluted more slowly in fraction II [4]. The pectic substances having no metoxyl group (pectic acid) were eluted in fraction III [4].

The results are shown in Fig. 4. The elution patterns of PA, PB and PC on chromatography were different between raw and 15 min cooked squashes. Almost all galacturonic acid of PA and PB in raw squash were eluted in fraction II, and only small amounts of them were eluted in fraction III. PA was eluted earlier than $\mathrm{PB}$ in fraction II; therefore, DE of PA was higher than $\mathrm{DE}$ of $\mathrm{PB}$. In addition, almost all of $\mathrm{PC}$ was eluted in fraction III. Also, the percentage of PC in squash was small, therefore, DE of pectin in squash was comparatively high.

After cooking, the elution patterns of PA and PB changed. Since the low methoxyl pectin was usually eluted later in fraction II, DE of PB especially decreased during cooking. The high methoxyl pectin was released into the cooking solution, thus comparatively

Table 1 The amount of galacturonic acid and the DE of pectic substances extracted from spaghetti squash.

\begin{tabular}{llll}
\hline & Types of pectin & Amount of galacturonic acid $(\mathrm{mg} / 100 \mathrm{~g})$ & $\mathrm{DE}(\%)$ \\
\hline \multirow{4}{*}{ Raw } & PA & 237.4 & 67.4 \\
& PB & 99.6 & 61.5 \\
& PC & 7.3 & 55.6 \\
& Total & 344.3 & \\
\hline \multirow{5}{*}{ Cooked in distilled water for $15 \mathrm{~min}$} & PA & 73.8 & 69.4 \\
& PB & 68.6 & 51.0 \\
& PC & 35.8 & 50.8 \\
\hline
\end{tabular}

PA: $0.01 \mathrm{~N} \mathrm{HCl}$ soluble pectin; PB: $0.1 \mathrm{M}$ acetate buffer soluble pectin; PC: $2 \%$ sodium hexametaphosphate soluble pectin. 
Relationship between Pectic Substances and Strand Separation of Cooked Spaghetti Squash-Part 1. 181 Changes in Pectic Substances during Cooking

Raw

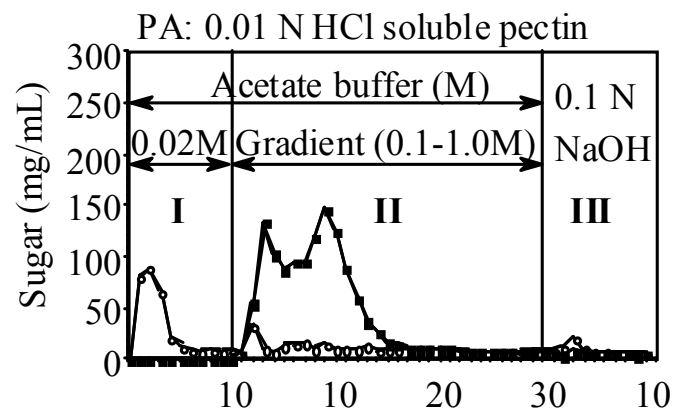

PB: $0.1 \mathrm{M}$ acetate buffer soluble pectin

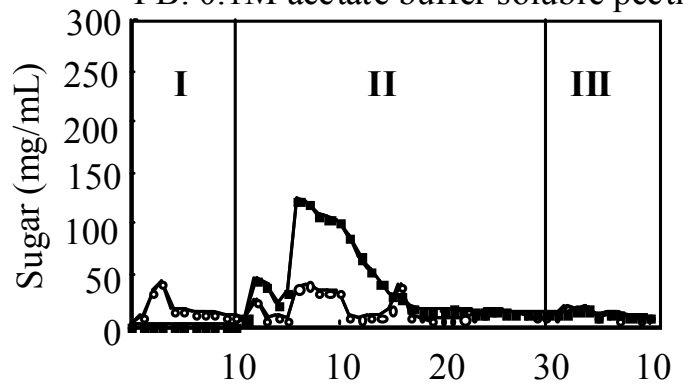

PC: $2 \%$ sodium hexametaphosphate soluble pectin

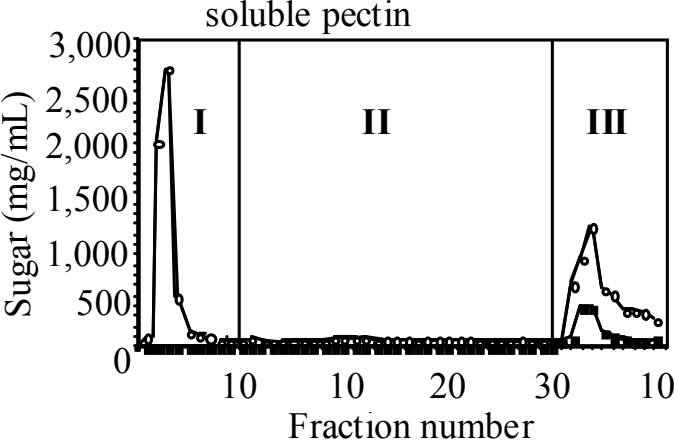

\section{Cooked for $15 \mathrm{~min}$}

PA: $0.01 \mathrm{~N} \mathrm{HCl}$ soluble pectin

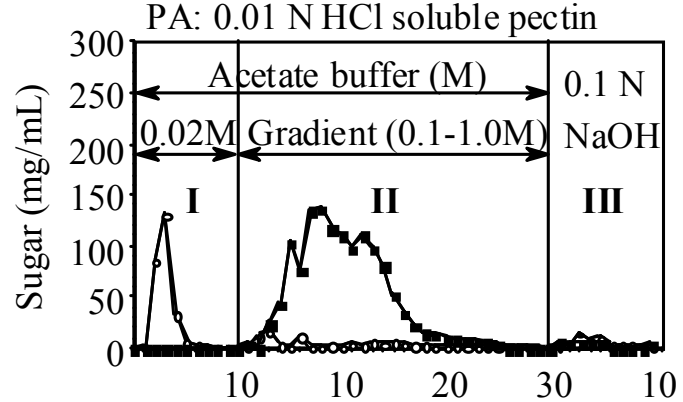

PB: $0.1 \mathrm{M}$ ace tate buffer soluble pectin

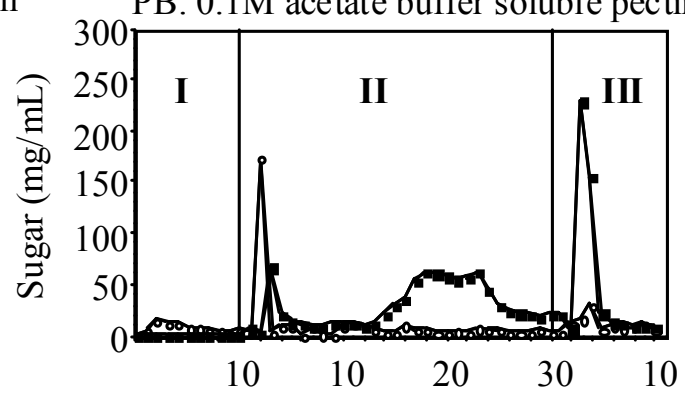

PC: $2 \%$ sodium hexametaphosphate

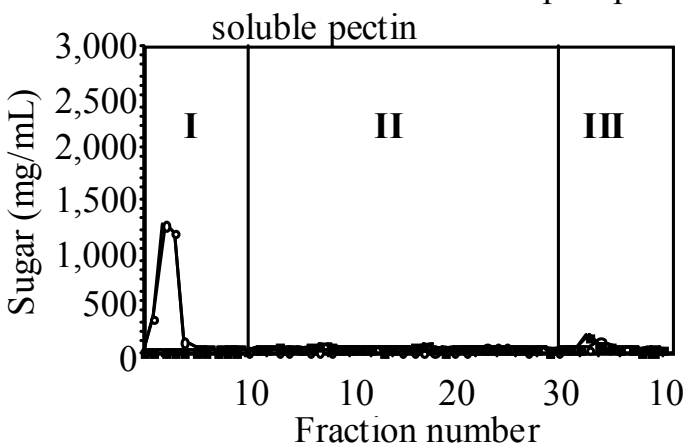

Fig. 4 DEAE-cellulose column chromatograms of pectic substances in raw and cooked spaghetti squash.

n: Galacturonic acid, ○: neutral sugar. The eluate was divided into $10 \mathrm{~mL}$.

Table 2 The amount of dietary fiber and the percentage of PA, PB and PC.

\begin{tabular}{|c|c|c|c|c|c|c|c|}
\hline \multirow[t]{2}{*}{ Vegetables } & \multicolumn{4}{|c|}{ Dietary fiber ( $\mathrm{mg} \%$ on a fresh weight basis) } & \multicolumn{3}{|c|}{ Pectin ( $\%$ of PA, PB and PC) } \\
\hline & Cellulose & Hemicellulose & Lignin & Pectin & PA & $\mathrm{PB}$ & $\mathrm{PC}$ \\
\hline Spaghetti squash & 691 & 209 & 48 & 344 & 69.0 & 28.9 & 2.1 \\
\hline Bamboo shoot* & 1,003 & 1,677 & 72 & 133 & 8.2 & 2.2 & 88.6 \\
\hline East Indian lotus* & 544 & 126 & 82 & 217 & 30.9 & 55.7 & 13.4 \\
\hline Edible burdock* & 2,249 & 88 & 301 & 985 & 38.4 & 53.9 & 6.7 \\
\hline Carrot* & 1,036 & 9 & 101 & 849 & 63.5 & 33.9 & 2.6 \\
\hline Japanese radish* & 501 & 252 & 48 & 410 & 45.0 & 47.3 & 7.7 \\
\hline Potato* & 981 & 655 & 155 & 287 & 76.8 & 15.6 & 7.6 \\
\hline
\end{tabular}

*Ref. [5]; PA: $0.01 \mathrm{~N} \mathrm{HCl}$ soluble pectin; PB: 0.1 M acetate buffer soluble pectin; PC: 2\% sodium hexametaphosphate soluble pectin.

low methoxyl pectin remained in cooked squash.

The monosaccharide composition of pectic substances (fractions II and III) in spaghetti squash separated by DEAE-cellulose column chromatography is shown in Table 3. The percentage of galactose/neutral sugar in raw samples was highest, and 
Table 3 Monosaccharide composition of pectic substances in spaghetti squash separated by DEAE-cellulose column chromatography.

\begin{tabular}{|c|c|c|c|c|c|c|c|c|}
\hline \multirow{2}{*}{ Types of pectin } & \multirow{2}{*}{ Raw or cooked } & \multirow{2}{*}{ Fraction } & \multicolumn{6}{|c|}{ Composition of monosaccharides (\%) } \\
\hline & & & Rhamnose & Arabinose & Xylose & Mannose & Galactose & Glucose \\
\hline \multirow{4}{*}{ PA } & \multirow{2}{*}{ Raw } & II & 12.3 & 24.3 & 8.2 & 5.6 & 49.0 & trace \\
\hline & & III & 5.4 & 7.0 & 14.3 & 18.2 & 32.1 & 23.1 \\
\hline & \multirow{2}{*}{$\begin{array}{l}\text { Cooked for } 15 \\
\text { min }\end{array}$} & II & 17.6 & 21.9 & 2.2 & 3.3 & 55.0 & trace \\
\hline & & III & 3.3 & 12.7 & 0.5 & 18.7 & 49.3 & 15.5 \\
\hline \multirow{4}{*}{ PB } & \multirow{2}{*}{ Raw } & II & 21.5 & 13.1 & 10.8 & 9.3 & 28.1 & 17.3 \\
\hline & & III & 7.9 & 11.2 & 7.4 & 23.8 & 18.1 & 34.7 \\
\hline & \multirow{2}{*}{$\begin{array}{l}\text { Cooked for } 15 \\
\min \end{array}$} & II & 21.0 & 7.4 & 5.5 & 4.2 & 36.5 & 25.4 \\
\hline & & III & 18.8 & 2.2 & 0.0 & 10.5 & 15.2 & 10.6 \\
\hline
\end{tabular}

PA: $0.01 \mathrm{~N} \mathrm{HCl}$ soluble pectin; PB: $0.1 \mathrm{M}$ acetate buffer soluble pectin.
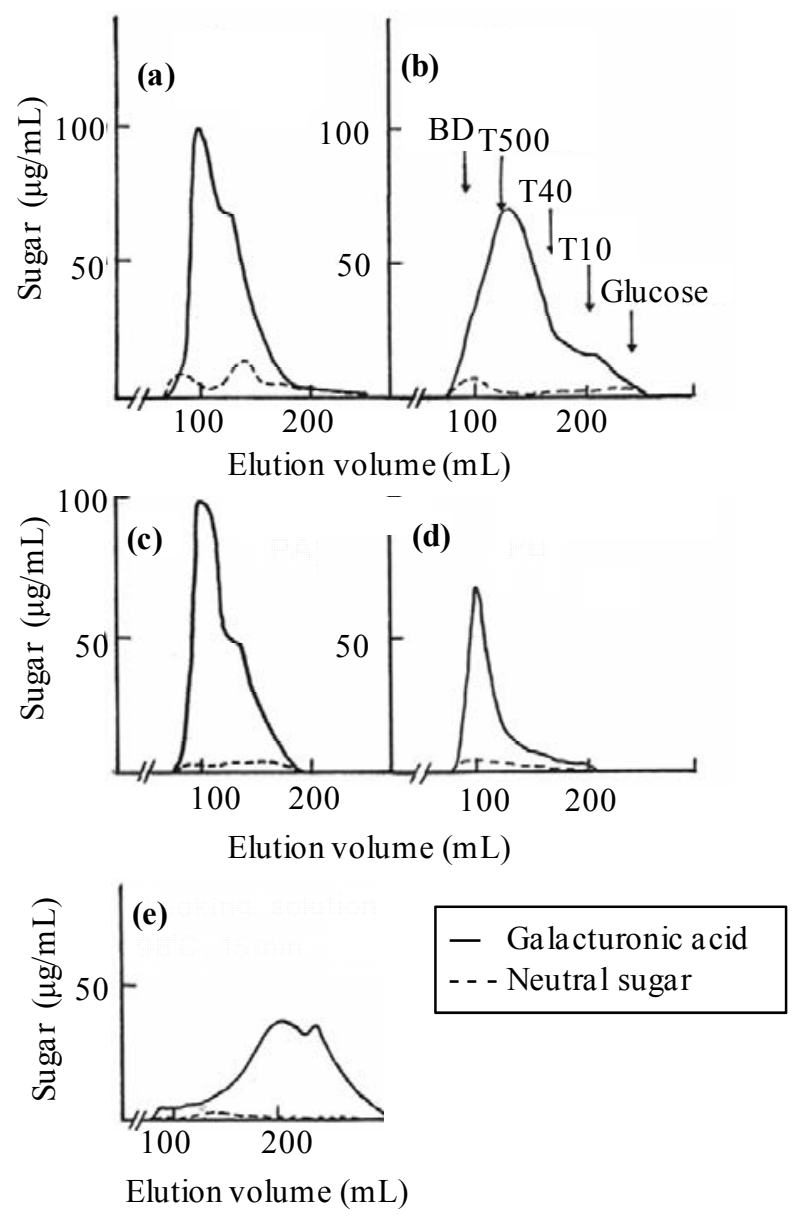

Fig. 5 Changes in gel-filtration profiles (Sepharose CL-6B) of pectic substances in spaghetti squash during cooking for 15 min.

(a) PA extracted from raw flesh; (b) PB extracted from raw flesh; (c) PA extracted from flesh cooked for $15 \mathrm{~min}$; (d) PB extracted from flesh cooked for $15 \mathrm{~min}$; (e) cooking solution after cooking for $15 \mathrm{~min}$.

the percentages of arabinose and rhamnose were comparatively high. Thus, it is suggested that galactan and arabinan are attached with rhamnose residues, the major branch point of the main chain of pectin (rhamno-galacturonan).

When cooked for $15 \mathrm{~min}$, the percentage of galactose in fraction II of PA and PB increased, while that of arabinose, xylose and mannose decreased. This suggests that low methoxyl pectin with galactose remained in strands after cooking and maintained the firmness of strands. While pectic substances adhering strands might contain high methoxyl pectin with arabinose, xylose and mannose. High methoxyl pectin easily broke down by $\beta$-elimination during boiling [2-5]. Consequently, the flesh separated into strands.

Changes in gel-filtration profiles (Sepharose CL-6B) of pectic substances in spaghetti squash during cooking for $15 \mathrm{~min}$ are shown in Fig. 5. The MW of PA $\left(1 \times 10^{6}-5 \times 10^{5}\right)$ in raw tissue was higher (Fig. 5a) than MW of PB (peak: $5 \times 10^{5}$, the range of MW distribution: from $5 \times 10^{5}$ to $1 \times 10^{4}$ ) (Fig. $5 \mathrm{~b}$ ). After cooking for $15 \mathrm{~min}, \mathrm{MW}$ of PA remaining in tissue did not change (Fig. 5c), but PB with low MW $\left(5 \times 10^{5}-1 \times 10^{4}\right)$ eluted into cooking solution and PB with only high MW $\left(1 \times 10^{6}\right)$ was remained (Fig. 5d). The MW of pectin eluted in cooking solution was comparatively low $\left(<1 \times 10^{4}\right)$ (Fig. 5e). However, the distribution of MW was wide; not only the monosaccharide but also a macromolecule $\left(1 \times 10^{4}\right)$ was included. 
Relationship between Pectic Substances and Strand Separation of Cooked Spaghetti Squash-Part $1 . \quad 183$ Changes in Pectic Substances during Cooking

\section{Conclusions}

Spaghetti squash separated into strands when boiled for $15 \mathrm{~min}$ with stirring. After cooking, the shape of round cells which contributed the strands was maintained, but the elongated cells which surrounded the strands broke down. About $50 \%$ of pectic substances in flesh were released into a cooking solution. Raw flesh contained high methoxyl pectin (67.4\% esterified) of $69.0 \%$. High methoxyl pectin was degraded by $\beta$-elimination during boiling; consequently, the flesh was separated into strands. This suggests that high methoxyl pectin glues strands together in the flesh of spaghetti squash. When boiling was continued until $30 \mathrm{~min}$, release of pectin did not increase. This suggests that low methoxyl pectin remains in the strands and other dietary fiber are regarded as a cause of crisp texture.

\section{Acknowledgments}

A part of this work was supported by a grant-in aid for scientific research from the Ministry of Education, Science, Sports and Culture in Japan.

\section{References}

[1] J.P. van Buren, The chemistry of texture in fruits and vegetables, J. Texture Studies 10 (1979) 1-23.

[2] M. Fuchigami, K. Okamoto, Fractionation of pectic substances in several vegetables by successive extraction with dilute hydrochloric acid and acetic buffer solutions, J. Jap. Soc. Nutri. Food Sci. 37 (1984) 57-64. (in Japanese)

[3] M. Fuchigami, Relationship between maceration and pectic compositions of vegetable tissues during cooking, J. Home Econ. 38 (1987) 465-475. (in Japanese)

[4] M. Fuchigami, Relationship between pectic compositions and the softening of the texture of Japanese radish roots during cooking, J. Food Sci. 52 (1987) 1317-1320.

[5] M. Fuchigami, Difference between bamboo shoots and vegetables in thermal disintegration of tissues and polysaccharides fractionated by successive extraction, J. Food Sci. 55 (1990) 739-745.

[6] P. Albersheim, H. Neukom, H. Deuel, Splitting of pectic chain molecules in neutral solutions, Arch. Biochem. Biophys. 90 (1960) 46-51.

[7] H. Neukom, H. Deuel, About the decomposition of pectic substance by alkaline reaction, Beiheft Zeitschr. Schweiz Forstv. 30 (1960) 223-235. (in German)

[8] S. Tamura, M. Fuchigami, H. Okuda, Effects of salts on softening of cooked Japanese radish roots, in: Seventh Symposium on Salts, Amsterdam, 1993, pp. 637-644.

[9] J.T. Galumbos, The reaction of carbazole with carbohydrate-I. Effect of borate and sulfamate on the carbazole color of sugars, Anal. Chem. 19 (1969) 119-132.

[10] L.B. Baltolome, J.E. Hoff, Gas chromatographic methods for the assay of pectin methylesterase, free methanol and methoxy group in plant tissues, J. Agri. Food Chem. 20 (1972) 262-266.

[11] P.J. van Soest, R.H. Wine, Determination of lignin and cellulose in acid-detergent fiber with permanganate, Journal of the Association of Official Analytical Chemists 51 (1986) 780-785.

[12] M. Dubois, K.A. Gilles, J.K. Hamilton, P.A. Rebers, F. Smith, Colorimetric method for determination of sugars and related substances, Anal. Chem. 25 (1956) 350-356.

[13] C. Hatanaka, J. Ozawa, Enzymic degradation of pectic acid, Agri. Biol. Chem. 28 (1964) 627-632.

[14] I. Kusakabe, Y. Kamiyama, T. Yasui, Methyl $\beta$-D-glucoside as a satisfactory internal standard in gas-liquid chromatographic quantitative-analysis of alditolacetates derived from monosaccharides, J. Agri. Chem. Soc. 51 (1977) 41-43. (in Japanese)

[15] M. Fuchigami, Y. Kishigami, A. Sasaki, Pectic polysaccharides in edible burdock root, J. Home Econ. 41 (1990) 957-963. (in Japanese) 